
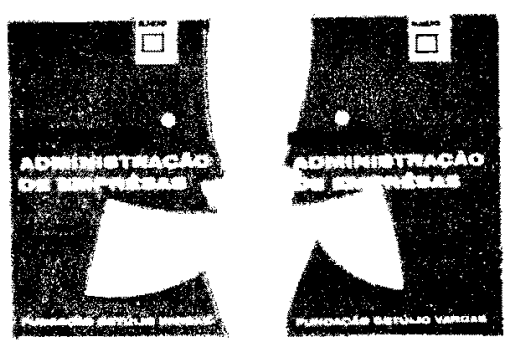

\title{
FORUM DE OPINIÖES
}

Com o intuito de avaliar o grau de receptividade da REVISTA DE ADMINISTRAÇÃo DE EMPRÊSAS junto a seus leitores conduzimos uma pesquisa em São Paulo (Capital), cujos principais resultados aqui transcreveremos.

$O$ inquérito foi realizado por meio de entrevistas pessoais baseadas num questionário composto de perguntas "abertas", a fim de dar aos entrevistados a oportunidade de tecer seus comentários com total liberdade. Ao todo, foram entrevistados 73 dos nossos leitores.

QUEM SÃO OS LEITORES DA RAE?

Como selecionamos os entrevistados a partir de um processo aleatório a fim de a todos oferecer igual oportunidade de serem escolhidos, as opinióes expressas devem ser bastante representativas para a média dos assinantes da RAE, ao menos no concernente à cidade de São Paulo.

- A tabulação dos dados referentes à escolaridade dos respondentes demonstrou claramente que êstes são, na maioria, diplomados em cursos superiores (vide Quadro 1), sobretudo de Administração (29\%) e de Ciências Econômicas $(25 \%)$. 
QUADRo 1: Escolaridade dos Entrevistados

\begin{tabular}{|c|c|c|}
\hline Discriminação & N.O & $\%$ \\
\hline $\begin{array}{l}\text { Administraçäo } \\
\text { Economia } \\
\text { Engenharia } \\
\text { Direito } \\
\text { Contabilidade } \\
\text { Outros cursos }\end{array}$ & $\begin{array}{r}21 \\
18 \\
12 \\
10 \\
8 \\
4\end{array}$ & $\begin{array}{r}28,8 \\
24,7 \\
16,4 \\
13,7 \\
10,9 \\
5,5\end{array}$ \\
\hline Total & 73 & 100,0 \\
\hline
\end{tabular}

- Quanto às ocupações dos respondentes (vide Quadro 2 ), verificamos que a maioria exerce funções de chefia (62\%) ou de assessoria ( $27 \%$ ) nas emprêsas em que trabalham.

Quapro 2: Cargo ou ocupação dos Entrevistados

\begin{tabular}{l|r|r}
\hline \multicolumn{1}{c|}{ Discriminaçä́o } & N. & $\%$ \\
\hline Diretor & & \\
Chefe de Departamento & 12 & 27,5 \\
Assistente de Diretoria & 9 & 16,4 \\
Gerente & 8 & 12,3 \\
Auditor, Contador & 6 & 10,9 \\
Proprietário & 5 & 8,2 \\
Secretário, Assistente & 5 & 6,9 \\
Outros (professôres, alunos etc.) & 8 & 6,9 \\
\hline \multicolumn{1}{c}{ Total } & 73 & 10,9 \\
\hline
\end{tabular}

Êsses dados confirmam nossa hipótese de que a RAE encontra maior receptividade entre os homens que - fre. qüentemente com formação acadêmica - dirigem os des* tinos de organizações fabris e comerciais. 